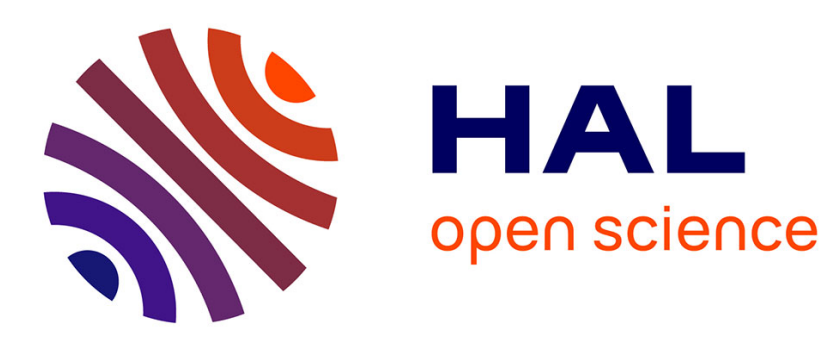

\title{
Are performance-avoidance goals always deleterious for academic achievement in college? The moderating role of social class
}

Alisée Bruno, Mickaël Jury, Marie-Christine Toczek, Céline Darnon

\section{- To cite this version:}

Alisée Bruno, Mickaël Jury, Marie-Christine Toczek, Céline Darnon. Are performance-avoidance goals always deleterious for academic achievement in college? The moderating role of social class. Social Psychology of Education, 2019, 22 (3), pp.539-555. hal-01991735

\section{HAL Id: hal-01991735 \\ https://hal.science/hal-01991735}

Submitted on 30 Jan 2019

HAL is a multi-disciplinary open access archive for the deposit and dissemination of scientific research documents, whether they are published or not. The documents may come from teaching and research institutions in France or abroad, or from public or private research centers.
L'archive ouverte pluridisciplinaire HAL, est destinée au dépôt et à la diffusion de documents scientifiques de niveau recherche, publiés ou non, émanant des établissements d'enseignement et de recherche français ou étrangers, des laboratoires publics ou privés. 


\title{
Are Performance-Avoidance Goals Always Deleterious for Academic Achievement in College? The Moderating Role of Social Class."
}

\author{
Alisée Bruno $^{1}$, Mickaël Jury ${ }^{2,3}$, Marie-Christine Toczek-Capelle ${ }^{3}$, Céline Darnon ${ }^{1 \dagger}$ \\ ${ }^{1}$ Université Clermont Auvergne, Laboratoire de Psychologie Cognitive et Sociale, LAPSCO, UMR6024, CNRS \\ ${ }^{2}$ ESPE Lille Nord de France, Laboratoire PSITEC, EA 4072 \\ ${ }^{3}$ ESPE Clermont Auvergne, Laboratoire ACTE, EA 4281
}

\begin{abstract}
Abundant research has shown that the endorsement of performance-avoidance goals in academic contexts is associated with negative outcomes, including poor academic achievement. The present study tests students' social class as a moderator of the relationship between performance-avoidance goals and achievement. Two hundred thirty students (106 lower-class students and 124 upper-class students, $M_{\text {age }}=$ $18.57, S D=1.28$ ) were asked to report the highest academic degree obtained by their mother and father and complete a performance-avoidance goal scale. Participants' initial academic level was measured. In addition, depending on the condition, they were led to believe they had great (vs. poor) chances to succeed at the university. They then solved Advanced Progressive Matrices measuring their achievement. As expected, performance-avoidance goals negatively predicted achievement only for lower-class students, and this moderation mainly appeared for high academic achievers. The manipulation of the success vs. failure expectancies did not moderate the effect. These results confirm that the adoption of performanceavoidance goals would be especially deleterious for lower-class students who succeed, supporting an interpretation in terms of the upward mobility process lower-class students achieve when succeeding in higher education.
\end{abstract}

Keywords: Performance-avoidance goals; Achievement, Social class; First generation; College, upward mobility.

\section{Introduction}

In the achievement goal literature, avoidance goals (i.e., mastery-avoidance and performanceavoidance goals) are usually identified as deleterious forms of motivation (for a review, see Moller and Elliot, 2006). In particular, research on performance-avoidance goals (i.e., trying not to perform poorly) has led to a large consensus: the endorsement of these goals is related to several negative academic outcomes, including academic achievement (Darnon, Butera, Mugny, Quiamzade, and Hulleman, 2009; Durik, Lovejoy, and Johnson, 2009; Elliot and Murayama, 2008; Elliot, Murayama, and Pekrun, 2011; Huang, 2012; Meece, Anderman, and Anderman, 2006; Van Yperen, Blaga, and Postmes, 2014). However, recent research has pointed out that the endorsement of these goals does not have the same consequences for all categories of individuals (Chalabaev, Major, Sarrazin, and Cury, 2012; Deemer, Smith, Carroll, and Carpenter, 2014). In the present paper, we seek to examine social class and academic abilities as moderators of the link between performance-avoidance goal endorsement and achievement in a college context.

\section{Performance-Avoidance Goals and Academic Achievement}

A central question in the achievement goal literature is the extent to which different types of goals facilitate or undermine academic achievement (e.g., Barron and Harackiewicz, 2001; Midgley, Kaplan, and Middleton, 2001). Therefore, a large amount of research has investigated whether the endorsement of mastery-approach (i.e., trying to learn), masteryavoidance (i.e., trying to avoid not learning), performance-approach (i.e., trying to outperform others), and performance-avoidance goals is related to academic achievement and under which conditions (for meta-analyses, see Hulleman, Schrager, Bodmann, and Harackiewicz, 2010; Linnenbrink-Garcia, Tyson,

\footnotetext{
*This paper has been accepted for publication in Social Psychology of Education. This version is a post-print.

† This research was supported by the Conseil Régional Rhône-Alpes-Auvergne. Correspondance should be adressed to Céline Darnon, Laboratoire de Psychologie Sociale et Cognitive, Université Clermont Auvergne, 34 Avenue Carnot, 63037 Clermont-Ferrand Cedex, France (celine.darnon@uca.fr). The authors declare that there are no potential conflicts of interest with respect to the research, authorship, and/or publication of this article.
} 
and Patall, 2008; Van Yperen et al., 2014).

Earlier work has argued that mastery goals should be positively related to academic outcomes while performance goals should not (Dweck, 1986; Elliott and Dweck, 1988). However, data did not always support this claim (Barron and Harackiewicz, 2003; Harackiewicz, Barron, Pintrich, Elliot, and Thrash, 2002; Midgley et al., 2001; Kaplan and Middleton, 2002). The introduction of the approach/avoidance distinction for performance goals (Elliot and Church, 1997) helped draw clearer conclusions. Indeed, if performanceapproach goals are usually positively associated with academic success (Harackiewicz, Barron, Tauer, and Elliot, 2002; Harackiewicz, Barron, Tauer, Carter, and Elliot, 2000), at least in some conditions (Dompnier, Darnon, and Butera, 2013; Grant and Dweck, 2003), performanceavoidance goals are consistently related to negative academic outcomes. For example, the endorsement of performance-avoidance goals is associated with the use of surface learning or disorganization (Coutinho and Neumann, 2008; Darnon and Butera, 2005; Elliot and McGregor, 2001; Elliot, 1999; Howell and Watson, 2007), self-handicapping (Lovejoy and Durik, 2010; Urdan, 2004), low help-seeking (Karabenick, 2003, 2004; Poortvliet and Darnon, 2010; Roussel, Elliot, and Feltman, 2011), and low intrinsic motivation (Elliot and Church, 1997; Elliot and Harackiewicz, 1996; Elliot and Murayama, 2008; Elliot et al., 2011). More importantly, performance-avoidance goals usually negatively predict academic achievement (Elliot and Murayama, 2008; Huang, 2012; Hulleman et al., 2010; Van Yperen et al., 2014).

Although this research mainly reports the main effects of performance-avoidance goal endorsement on academic outcomes, recent meta-analyses suggest the existence of potential moderators of this effect. For example, the strength of the link between performanceavoidance goals and academic achievement could depend on the achievement goal measure (Hulleman et al., 2010), the achievement domain (Van Yperen et al., 2014), one's culture (Hulleman et al., 2010; King, 2016), or even one's gender (Chalabaev et al., 2012; Deemer et al., 2014). Interestingly, Huang (2012) recently called for more research examining the moderating effects of important demographic variables, such as students' social class. Following this recommendation, Darnon, Jury, and Aelenei (2018) recently showed that students' social class could moderate both the effects of performance-approach goals and mastery-approach goals on students' academic achievement. Indeed, performance-approach goal endorsement appeared to be positively associated with achievement only for upper-class students whereas mastery-approach goals tended to do so only for lower-class students. However, in this research, performance-avoidance goals were not examined. In the present paper, we argue that, in a higher education context, students' social class can also moderate the effect of performance-avoidance goals on academic achievement.

\section{Social Class as a Moderator of the link between Performance-Avoidance Goals and Achievement}

According to Elliot (1999), performanceavoidance goals are deleterious for achievement due to the prospect of potential failure that impairs affective and cognitive resources needed for a task (see also Elliot and Harackiewicz, 1996). Individuals who pursue performanceavoidance goals "construe the achievement setting as a threat, because they perceive the demands of the task as outweighing their resources" (Chalabaev, Major, Cury, and Sarrazin, 2009, p. 991). In fact, upper-class individuals are more equipped (i.e., have more resources) than lower-class students to face these cognitive and affective disruptions and, thus, are less likely to suffer from performance-avoidance goal adoption than lower-class students. Indeed, converging evidence in the field has shown that lower-class individuals are particularly likely to perceive their environment as threatening and to experience heightened reactions compared to upper-class individuals (Kraus, Piff, MendozaDenton, Rheinschmidt, and Keltner, 2012). For example, lower-class individuals often anticipate hostile emotions from others (Kraus, Horberg, Goetz, and Keltner, 2011). In the same vein, lower-class children are more likely to display heightened cardiovascular reactivity during stressful situations than upper-class children because they appraise ambiguous social situations as threatening (Chen and Matthews, 2001).

In addition, according to Elliot and Harackiewicz (1996, p. 462), adopting performance-avoidance goals elicits "anxietybased preoccupation with self-presentational rather than the task." Supporting this idea, recent research has documented that the negative effects of induced performance-avoidance goals on achievement were particularly likely to occur after a failure, with a mediation by "self-related 
thoughts" (Dickhauser, Buch, and Dickhauser, 2011). Because of their poor reputation in terms of competence (Croizet and Claire, 1998; Durante, Tablante, and Fiske, 2017; see also Fiske, Cuddy, Glick, and Xu, 2002), lower-class students are particularly concerned about how others perceive themselves. This is less the case of upper-class students who may have few doubts about their legitimacy within the college context (Ostrove and Long, 2007; Rubin, 2012) or their academic competence (Ivcevic and Kaufman, 2013; Kudrna, Furnham, and Swami, 2010; Ramos-Sanchez and Nichols, 2007). For these reasons, performance-avoidance goals should be more negatively related to achievement among lower-class than among upper-class students.

\section{Performance-Avoidance Goal, Academic Achievement, and the Upward Mobility Process}

Enrolling in higher education is a step, but succeeding in higher education is another one that appears to be particularly threatening for lower-class students (Destin and Debrosse, 2017; Jury, Bruno, and Darnon, 2018). Indeed, if they graduate, lower-class students, especially firstgeneration students (i.e., students whose neither parent graduated from higher education), will attain a higher level of education than that of their parents, meaning they are in an important and potentially costly upward mobility process. Social mobility involves identity changes that can be difficult to handle (Amiot, Terry, Wirawan, and Grice, 2010; DeRosa and Dolby, 2014; Jetten, Iyer, Tsivrikos, and Young, 2008; Ostrove and Long, 2007). In particular, when they experience upward mobility and discover a new social context, lower-class students feel a great sense of uncertainty about their own status and future identities (Destin and Debrosse, 2017). As a result, the threat lower-class students experience because of their background could be increased for those who are on track to achieve success.

In line with that idea, recent research has documented that the effect of social class on performance-avoidance goal endorsement in higher education was stronger for high academic achievers than for low academic achievers (Jury, Smeding, Court, and Darnon, 2015) and stronger when lower-class students experienced success than when they experienced failure (Jury et al., 2018). This work leads to the thinking that the

\footnotetext{
${ }^{\ddagger}$ We certify that all the measures and experimental conditions of the study are reported in the manuscript. The full material of this
}

endorsement of performance-avoidance goals may therefore be particularly harmful for competent lower-class students - namely, those who are the closest to experience upward mobility.

\section{Overview and Hypotheses}

In the present research, the association between performance-avoidance goal endorsement and achievement will be examined among lower-class (i.e., first generation) and upper-class (i.e., continuing generation) students who are in an upward mobility process (i.e., receive positive feedback or have high academic ability) or not (i.e., receive negative feedback or have poor academic ability). First, we expect social class to moderate the effect of performance-avoidance goals on achievement. More precisely, the negative link between performance-avoidance goals and achievement should be stronger for lower-class students than for upper-class students. Moreover, this interaction should be moderated by both the initial level of academic achievement and a manipulation of the expectancy of success versus failure. Indeed, as developed above, lower-class students who suffer the most in a higher education context are those who experience upward mobility (Jury et al., 2018). Consequently, the above effect (moderation of the effect of performance-avoidance goals by social class) should be stronger among students who are on track to achieve upward mobility. Thus, it should be stronger among high academic achievers than among low academic achievers. For the same reasons, it should also be stronger for students who receive positive feedback regarding their chances of success at the university than for those who receive negative feedback.

\section{Method}

\section{Participants and Procedure}

An a priori power analysis was conducted to determine our sample size. Assuming a low effect size $\left(\eta_{\mathrm{p}}{ }^{2}=.04\right), 191$ participants were required to have $80 \%$ chances to detect our effect. To increase safety margins, we planned to run 230 participants. Participants were 231 undergraduate psychology students who volunteered to participate to this study in exchange for course credit. Because of one missing data on the initial abilities measure, our final sample included 230

study as well as the raw data are available on Open Science Framework at osf.io/375a8. 
participants: 197 women and 33 men, with a mean age of 18.57 years $(S D=1.28)$. In the present sample, women represented more than $85 \%$, which corresponds to the usual distribution of students in Psychology.

The experiment was presented as part of a national survey on success in higher education. Participants were received by groups of five in the lab. They were first asked to report the highest academic degree obtained by their mother and father and then to complete a measure of performance-avoidance goals. Afterward, they carried out a task presented as highlighting the qualities of logic and reasoning necessary to succeed at the university. Participants were told that successful completion of this task strongly predicted success in the bachelor's degree program. This task was a short version of Advanced Progressive Matrices (Arthur and Day, 1994). Participants analyzed a series of symbols and had to choose the one (from among eight proposals) that would the most appropriately complete the series. Participants first completed five matrices (i.e., the series of symbol), which were used as a basis for the bogus feedback they would receive. They then carried out the main achievement task, which consisted of six other matrices from the Advanced Progressive Matrices. After the task, participants reported demographic information and the grade they obtained on the baccalaureate (i.e., the French high-school exit exam). Finally, they were all debriefed and thanked for their participation.

\section{Measures}

Social class. Based on previous research (Jury et al., 2015; Stephens, Fryberg, Markus, Johnson, and Covarrubias, 2012), parental level of education was used to assess students' social class. Participants were asked to report their mothers' and fathers' highest academic degrees. Participants with at least one parent who had a higher-education degree were coded as continuing-generation students $(n=124)$. The others were coded as first-generation students ( $n$ $=106$ ).

Performance-avoidance goals. Two measures of performance-avoidance goals were used. The first one was extracted from Elliot and McGregor's (2001) Achievement Goal Questionnaire (in its French version, validated by Darnon and Butera, 2005). This measure contained three items (e.g., "I just want to avoid doing poorly in my studies"; $\alpha=.50, M=4.79$, $S D=1.17)$ and is frequently used in research on self-set achievement goals (for examples, see
Brodish and Devine, 2009; Jury et al., 2015; Jury et al., 2018). However, a revised version (Elliot and Murayama, 2008) with items referring more explicitly to others (e.g., "My goal is to avoid having worse performance than other students") has emerged in the literature. In the present study, this revised goal measure, labeled "otheravoidance goals" $(\alpha=.84, M=3.13, S D=1.42)$ was also included. For both measures, participants had to answer on a 7-point scale from 1 "not at all true of me" to 7 "very true of me" regarding their goals for their studies "in general". It is worth noting that preliminary analyses tested whether social class impacted performance-avoidance and other-avoidance goals. These analyses revealed no effect of social class on either performance-avoidance goals, $B=$ $-0.07, t(228)=-0.96, p=.34$, or other-avoidance goals, $B=-0.07, t(228)=-0.72, p=.48$.

Manipulation of failure versus success expectancies. The first five matrices served as a basis for the bogus feedback. Participants were told that the successful completion of this task strongly predicted success in the bachelor's degree program. Once completed, participants had to call the experimenter. The experimenter then gave them their bogus score, which was 80 for all participants. Participants were then asked to report this score on a scale, supposedly corresponding to their chances to pass their bachelor's degree program, but which differed depending on the condition. In the failure expectancy condition $(n=118)$, the score of 80 corresponded to a $10 \%$ chance of graduating. In the success expectancy condition $(n=112)$, the score of 80 corresponded to a $90 \%$ chance of graduating.

Achievement. The performance obtained on the main task-namely, the six other Raven's Standard Progressive Matrices - served as an achievement measure. The score for these six items was calculated by adding the number of matrices adequately answered $(M=2.30, S D=$ 1.25).

Initial abilities. As participants were at the beginning of their studies, the mean grade they obtained on the high school exit exam (baccalaureate), which could range from 10 (passing level) to $20(M=12.27, S D=1.71$; current range from 8.80 to 17.30 ) was used as a measure of initial academic abilities. Intercorrelations among variables are presented in Table 1. 
Table 1.

Intercorrelations among variables

\begin{tabular}{lccccccc}
\hline & $\mathrm{M}$ & $\mathrm{SD}$ & 1 & 2 & 3 & 4 & 5 \\
\hline 1. Initial abilities & 12.27 & 1.71 & - & & & & \\
2. Performance-avoidance & 4.79 & 1.17 & -.10 & - & & & \\
goals & 3.13 & 1.42 & .04 & $.38^{* *}$ & & & \\
3. Other-avoidance goals & 2.30 & 1.25 & .11 & $-.12^{\mathrm{t}}$ & -.03 & & \\
4. Performance & - & - & -.05 & -.05 & -.04 & .08 & \\
5. Feedback condition & - & - & $.15^{*}$ & -.06 & -.05 & -.03 & -.09 \\
6. Social class & - & & & &
\end{tabular}

Note. ${ }^{\mathrm{t}} p<.10,{ }^{*} p<.05 .{ }^{* *} p<.01$

Table 2.

Summary of the two regression model ( $P A V$ and $O A V)$ results

\begin{tabular}{|c|c|c|c|c|c|c|}
\hline & \multicolumn{2}{|c|}{ Perf-avoidance goals (PAV) } & \multicolumn{4}{|c|}{ Other-avoidance goals (OAV) } \\
\hline & $B$ & $t$ & $p$ & $B$ & $t$ & $p$ \\
\hline $\begin{array}{l}\text { Manipulation of failure vs. success } \\
\text { expectancies (Cond) }\end{array}$ & .063 & 0.758 & .449 & .095 & 1.129 & .260 \\
\hline $\begin{array}{l}\text { Performance/other avoidance goals } \\
(P / O A V)\end{array}$ & -.199 & -2.717 & .007 & -.064 & -1.041 & .299 \\
\hline Initial abilities (IA) & .092 & 1.811 & .072 & .062 & 1.170 & .243 \\
\hline Social Class (SC) & -.094 & -1.129 & .260 & -.052 & -0.623 & .534 \\
\hline Cond X SC & .054 & 0.653 & .515 & .036 & 0.429 & .668 \\
\hline$P / O A V X S C$ & .183 & 2.496 & .013 & -.005 & -0.080 & .936 \\
\hline P/OAV X Cond & .058 & 0.789 & .431 & .022 & 0.353 & .725 \\
\hline$P / O A V X S C X$ Cond & -.077 & -1.054 & .293 & .014 & 0.230 & .818 \\
\hline P/OAV X IA & -.006 & -0.141 & .888 & -.008 & -0.193 & .847 \\
\hline P/OAV X Cond X IA & .085 & 2.014 & .045 & -.020 & -0.500 & 617 \\
\hline$P / O A V X S C X I A$ & .078 & 1.854 & .065 & .092 & 2.299 & .022 \\
\hline P/OAV X SC X Cond X IA & -.108 & -2.575 & .011 & -.074 & -1.849 & .066 \\
\hline IA X Cond & -.113 & -2.219 & .028 & -.073 & -1.377 & .170 \\
\hline IA X SC & .057 & 1.115 & .266 & .048 & 0.912 & .363 \\
\hline IA X Cond X SC & .044 & 0.862 & .390 & .024 & 0.463 & .644 \\
\hline
\end{tabular}

Note. The expected effects are in italic.

\section{Results}

Regression analyses were conducted to test whether performance-avoidance goals interacted with social class, initial academic ability, and feedback to predict achievement. A first set of regressions tested the hypotheses with performance-avoidance goals. A second one tested the same hypotheses with other-avoidance goals. The results are summarized in Table 2.

\section{Performance-avoidance Goals}

The regression analyses included four predictors: social class (coded -1 for firstgeneration students and +1 for continuinggeneration students), feedback (coded -1 for failure feedback and +1 for success feedback), performance-avoidance goals and initial abilities (both mean-centered), as well as all possible interactions among these four terms. The main effect of performance-avoidance goals was significant, $B=-0.20, t(214)=-2.72, p=.007$, $\eta_{\mathrm{p}}{ }^{2}=.03,95 \%$ CI $[-0.34,-0.05]$. In line with existing results in the literature, the higher participants' performance-goal endorsement, the lower their achievement. The main effects of social class, $B=-0.09, t(214)=-1.13, p=.26$, and feedback condition, $B=0.06, t(214)=0.76, p=$ .45 , were not significant. More importantly, as expected, performance-avoidance goals interacted with social class, $B=0.18, t(214)=$ $2.50, p=.013, \eta_{\mathrm{p}}{ }^{2}=.02,95 \%$ CI $[0.03,0.32]$. This interaction is depicted in Figure 1. Simple slope analyses revealed that performanceavoidance goals negatively predicted achievement for first-generation students, $B=$ $0.36, t(214)=-3.32, p=.001, \eta_{\mathrm{p}}^{2}=.04,95 \%$ CI $[-.57,-.14]$, but not for continuing-generation students, $B=-0.03, t(214)<1$.

As developed above, we expected this 2-way interaction to be moderated by (1) the feedback and (2) the level of initial abilities. As far as feedback is concerned, contrary to the expectations, the 3-way interaction among social class, feedback condition, and performance 
avoidance-goals was not significant, $B=-0.08$, $t(214)=-1.05, p=.29$. As far as initial abilities are concerned, the expected 3-way interaction among social class, initial academic abilities, and performance avoidance-goals was marginal, $B=$ $0.08, t(214)=1.85, p=.065, \eta_{\mathrm{p}}{ }^{2}=.01,95 \%$ CI [$0.005,0.16]$. As depicted in Figure 2 , the moderation of the effect of performanceavoidance goals by students' social class discussed above was stronger (and significant) for those with a high level of initial abilities (i.e., one standard deviation above the mean), $B=$ $0.32, t(214)=3.16, p=.002, \eta_{\mathrm{p}}{ }^{2}=.04,95 \%$ CI $[0.11,0.51]$, than for those who have a low level of initial academic abilities (i.e., one standard deviation below the mean), $B=0.05, t(214)<1$.

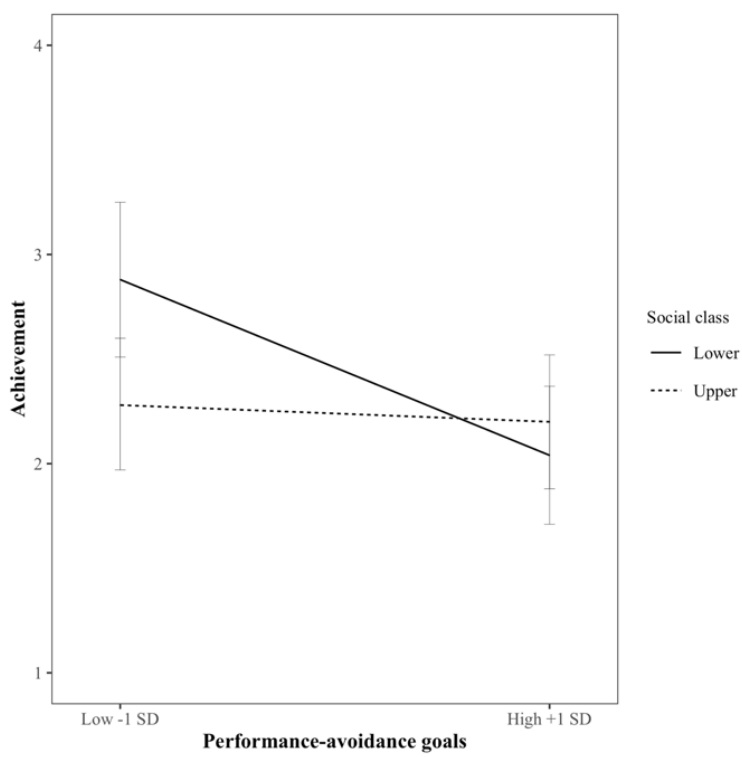

Figure 1. Achievement as a function of social class and performance-avoidance goal endorsement. Errors bars represent $95 \%$ confidence intervals.

Interestingly, and unexpectedly, the 4-way interaction among social class, feedback condition, performance-avoidance goals, and initial abilities was also significant, $B=-0.11$, $t(214)=-2.58, p=.011, \eta_{\mathrm{p}}{ }^{2}=.03,95 \%$ CI [-.19, $-.02]$. Further analyses indicated that the previously discussed interaction among social class, performance-avoidance goals, and initial abilities is only observed for participants in the failure condition, $B=0.19, t(214)=2.89, p=$
$.004, \eta_{\mathrm{p}}{ }^{2}=.03,95 \%$ CI $[0.05,0.31]$, but was not significant in the success condition, $B=-0.03$, $t(214)<1 .{ }^{\S}$

\section{Other-avoidance Goals}

Further regression analyses were conducted in order to test the same model with otheravoidance goals instead of performanceavoidance goals. As can be seen in Table 2, most of the relations identified with PAV goals go in the same direction as OAV goals, but are lower and mostly non-significant. None of the main effects were significant: $B=-0.06, t(214)=-1.04$, $p=.30$, for other-avoidance goals; $B=-0.05$, $t(214)<1$, for social class; $B=0.10, t(214)=$ $1.13, p=.26$, for feedback; and $B=0.06, t(214)$ $=1.17, p=.24$, for initial abilities. The expected interaction between other-avoidance goals and social class was not significant either, $B=-0.01$, $t(214)<1$.

Only two significant effects occurred. First, the expected interaction among social class, other-avoidance goals, and initial ability was significant, $B=0.09, t(214)=2.30, p=.022, \eta_{\mathrm{p}}{ }^{2}$ $=.02,95 \%$ CI $[0.01,0.17]$. Like performanceavoidance goals, simple effects analyses revealed that the expected interaction between otheravoidance goals and social class tends to be positive at a high level of initial academic abilities, although non-significant, $B=0.15$, $t(214)=1.54, p=.13, \eta_{\mathrm{p}}{ }^{2}=.01,95 \%$ CI [-0.04, $0.34]$. It became negative for students with a poor initial academic abilities, $B=-0.16, t(214)=-$ $1.91, p=.058, \eta_{\mathrm{p}}{ }^{2}=.01,95 \%$ CI [-0.32, 0.005]. Second, the 4-way interaction among otheravoidance goals, social class, feedback, and initial abilities was marginally significant, $B=$ $0.07, t(214)=-1.85, p=.066, \eta_{\mathrm{p}}^{2}=.01,95 \%$ CI $[-0.15,0.005]$.

As for performance-avoidance goals, the interaction among other-avoidance goals, social class, and initial abilities was significant for participants in the failure condition, $B=0.17$, $t(214)=2.57, p=.011, \eta_{\mathrm{p}}{ }^{2}=.03,95 \%$ CI [0.03, $0.29]$, but not for those in the success condition, $B=0.02, t(214)<1$.

\footnotetext{
$\S$ It is worth noting that the main effect of initial ability was marginal, $B=0.09, t(214)=1.81, p=.072, \eta_{\mathrm{p}}{ }^{2}=.01,95 \%$ CI [$0.008,0.19]$, the higher participants' initial ability, the higher they tend to achieve. Furthermore, feedback interacted with initial abilities, $B=-0.11, t(214)=-2.22, p=.028, \eta_{\mathrm{p}}{ }^{2}=.02,95 \%$ CI [-
} positively predicted achievement in the failure feedback condition, $B=0.21, t(214)=2.74, p=.007, \eta_{\mathrm{p}}{ }^{2}=.03,95 \%$ CI $[0.05,0.35]$, but was not significantly related to achievement in the success feedback condition, $B=-0.02, t(214)<1$. 

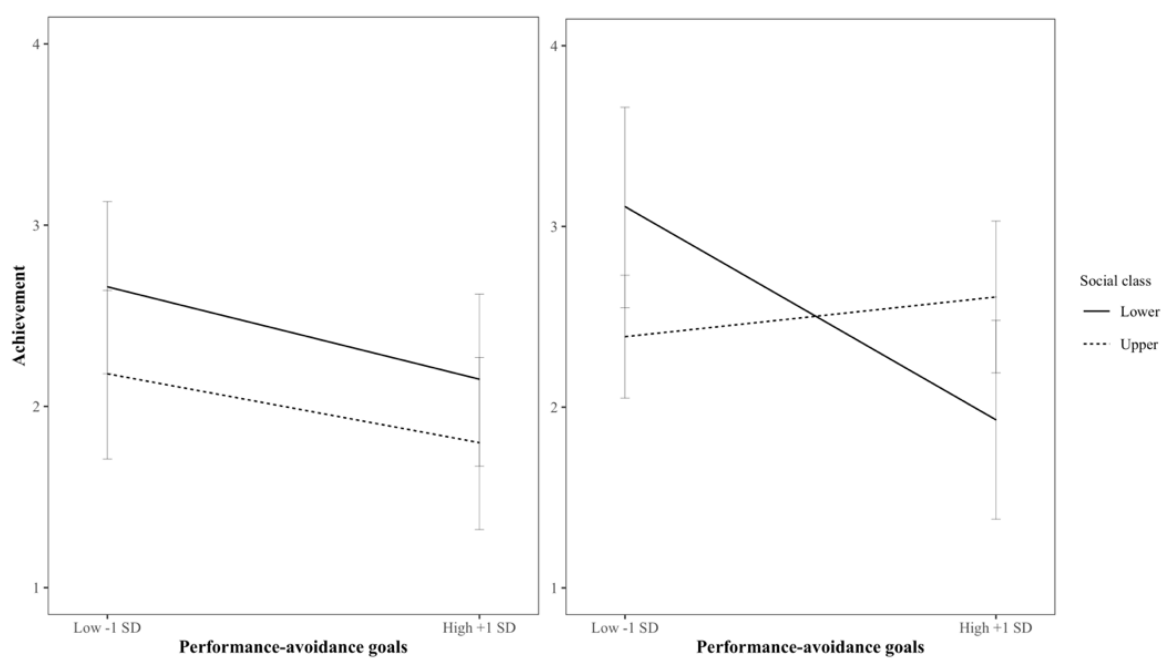

Figure 2. Achievement as a function of social class and performance-avoidance goal endorsement at a low level of initial abilities (-1 SD below the mean, left panel) and at a high level of initial abilities ( +1 SD above the mean, right panel). Errors bars represent $95 \%$ confidence interval.

No other effects reached significance (all $p \mathrm{~s}>$ .17). ${ }^{* *}$

\section{Discussion}

\section{Summary of the Findings}

The aim of the present paper was to test social class as a moderator of the link between performance-avoidance goals and achievement. As discussed herein, previous research has documented that lower-class students are particularly likely to perceive their environment as threatening; this perceived threat can, in turn, impair their achievement (Chen and Matthews, 2001; Croizet and Claire, 1998; Kraus and Stephens, 2012). Results obtained in the present study confirm that performance-avoidance goals were more negatively related to achievement for lower-class than for upper-class students. As such, the present finding confirms that social class has the potential to moderate not only the effects of mastery-approach and performanceapproach (Darnon et al., 2018) but also performance-avoidance goals. In addition, the identified interaction tended to be moderated by students' level of ability. Indeed, the endorsement of performance-avoidance goals tended to be the most disruptive for the highly competent lower-class students. Thus, in line

\footnotetext{
${ }^{* *}$ Since the reliability of the performance-avoidance goal score is quite low, in supplementary analyses, a global avoidance score was computed. This score aggregated the performance-avoidance and other-avoidance goal items $(\alpha=.73, M=3.96, S D=1.08)$. Then, the same regression model as before, but replacing performance-avoidance or other-avoidance goals by the global avoidance goal score was conducted. The main effect of performance-avoidance goals was significant, $B=-0.19, t(214)=$ $2.34, p=.020$. In addition, although performance-avoidance goals did not significantly interact with social class, $B=0.12, t(214)=$
}

with previous research (Jury et al., 2015), the present result supports upward mobility as one of the explanation of the difficulties encountered by lower-class students in the college context.

For similar reasons (i.e., the upward mobility process), we expected the interaction between performance-avoidance goals and social class to be stronger among participants who received positive feedback regarding their chances of success in higher education than among participants who received negative feedback. Thus, we expected the interaction between social class and performance-avoidance goals to be moderated not only by the academic level, but also by the manipulation of failure versus success expectancies. Contrary to our hypotheses, this was not the case, suggesting that the manipulation had less impact or was less strongly associated with the students' representation of their skills than their actual level. This finding is consistent with research showing that initial academic ability had a stronger influence and moderated the effect of other variables on academic achievement more often than manipulated expectancies (Harackiewicz et al., 2002; Senko and Harackiewicz, 2005). However, it is worth noting that the 4-way interaction was significant. Indeed, unexpectedly, social class

$1.54, p=.13$, the 3 -way interaction between social class, initial academic abilities, and performance avoidance-goals was significant, $B=0.14, t(214)=2.84, p=.005$. Just like for performance-avoidance goals, the moderation of the effect of performance-avoidance goals by students' social class was significant for high academic achievers (i.e., one standard deviation above the mean), $B=0.36, t(214)=2.98, p=.003$, but was not significant for low academic achievers (i.e., one standard deviation below the mean), $B=-0.12, t(214)=-1,05, p=.29$. 
interacted with performance-avoidance goals and initial abilities to predict achievement in the failure condition but not in the expected success condition. The fact that this interaction is a 4-way interaction, resulting in quite a low number of participants in each condition, prevents clear conclusions from being drawn on that issue. However, it seems reasonable to argue that contrary to the success condition, which may have reassured successful first-generation students, the failure condition might have been quite threatening for these students, raising doubts about their real ability to achieve upward mobility.

It is worth noting that the present research measured both performance-avoidance and other-avoidance goals. Other-avoidance goals proved to be less predictive of achievement than performance-avoidance goals. In addition, as evident in Table 2, the expected interactions appeared for performance-avoidance goals more so than for other-avoidance goals. Such a finding echoes other research showing that the negative relationship between performance-avoidance goals and achievement mostly occurs with measures that do not involve explicit social comparison (Hulleman et al., 2010; Key, Conley, Duncan, and Domina, 2012).

\section{Limitations}

Some limitations should be noted. First, in the present research, goals, social class, and initial abilities were all invoked variables. Therefore, causality cannot be established. Although situationally induced goals usually get similar results with invoked self-reported goals (Linnenbrink-Garcia et al., 2008; Van Yperen et al., 2014; Van Yperen, Blaga, and Postmes, 2015), replicating the present results with manipulated goals would nicely complement the present findings. Second, it should be noted that the internal consistency coefficient of the performance-avoidance goal scale is relatively weak $(\alpha=.51)$. The fact that the expected interaction is also observed with the more reliable other-avoidance goal scale $(\alpha=.84)$ gives us confidence on the validity of this finding. However, as mentioned earlier, the results obtained with performance-avoidance goals are not consistently obtained with other-avoidance goals, and the former seems to be more predictive of achievement than the latter (Table 2). For these reasons, we believe a more systematic comparison between the effects of these two measures is required to clarify the specific components of performance-avoidance goals (fear of failure, social comparison, avoidance orientation, etc.) that are deleterious for achievement. Third, our sample only involved psychology students and was not gender balanced (i.e., more than $85 \%$ of women). Because gender could moderate the effect of performanceavoidance goals (Chalabaev et al., 2012; Deemer et al., 2014), future research should replicate the present findings in different fields of study in order to increase the generalizability of the present findings. Finally, the present research did not measure perception of mobility. Thus, it is difficult to ensure that the moderation by academic ability is due to an upward mobility process experienced by high (but not low) academic achievers. For that reason, future research should test whether the perception of upward mobility (Jury et al., 2018) could mediate this interaction.

\section{Conclusion}

The effects of social class on various psychological outcomes, including academic performance, have attracted growing interest recently (e.g., Goudeau and Croizet, 2017; Jury et al., 2017; Stephens, Brannon, Markus, and Nelson, 2015). One of the results obtained in a higher education context is that lower-class students are particularly likely to endorse performance-avoidance goals, especially if they have a high level of performance (Jury et al., 2015). Linking this finding to the one reported in the present manuscript underscores that students who are the most likely to endorse performanceavoidance goals are also those who are the most likely to see their achievement impaired by the endorsement of these goals. Consequently, the underachievement of lower-class students is itself reinforced by their endorsement of the maladaptive forms of goals, confirming the tendency, for low-status group members, to sometime endorse self-debilitating beliefs and behaviors (Halabi, Dovidio, and Nadler, 2008; Jost, Gaucher, and Stern, 2015; Levin, Frederico, Sidanius, and Rabinowitz, 2000). We believe the present research illustrates this phenomenon in a higher education context.

\section{References}

Amiot, C. E., Terry, D. J., Wirawan, D., \& Grice, T. A. (2010). Changes in social identities over time: The role of coping and adaptation processes. British Journal of Social Psychology, 49(4), 803-826. doi: $10.1348 / 014466609 X 480624$.

Arthur Jr, W., \& Day, D. V. (1994). Development of a short form for the Raven Advanced Progressive Matrices Test. Educational and Psychological 
Measurement, 54(2), $10.1177 / 0013164494054002013$

$394-403$

doi:

Barron, K. E., \& Harackiewicz, J. M. (2001). Achievement goals and optimal motivation: Testing multiple goal models. Journal of Personality and Social Psychology, 80(5), 706722. doi: 10.1037//0022-3514.80.5.706

Barron, K. E., \& Harackiewicz, J. M. (2003). Revisiting the benefits of performance-approach goals in the college classroom: Exploring the role of goals in advanced college courses. International Journal of Educational Research, 39(4-5), 357374. doi: 10.1016/j.ijer.2004.06.004

Brodish, A. B., \& Devine, P. G. (2009). The role of performance-avoidance goals and worry in mediating the relationship between stereotype threat and performance. Journal of Experimental Social Psychology, 45(1), 180-185. doi: 10.1016/j.jesp.2008.08.005

Chalabaev, A., Major, B., Cury, F., \& Sarrazin, P. (2009). Physiological markers of challenge and threat mediate the effects of performance-based goals on performance. Journal of Experimental Social Psychology, 45(4), 991-994. doi: 10.1016/j.jesp.2009.04.009

Chalabaev, A., Major, B., Sarrazin, P., \& Cury, F. (2012). When avoiding failure improves performance: Stereotype threat and the impact of performance goals. Motivation and Emotion, 36(2), 130-142. doi: 10.1007/s11031011-9241-X

Chen, E., \& Matthews, K. A. (2001). Cognitive appraisal biases: An approach to understanding the relation between socioeconomic status and cardiovascular reactivity in children. Annals of Behavioral Medicine,23(2), 101-111. doi: 1207/S15324796ABM2302 4

Coutinho, S. A., \& Neuman, G. (2008). A model of metacognition, achievement goal orientation, learning style and self-efficacy. Learning Environments Research,11(2), 131-151. doi: 10.1007/s10984-008-9042-7

Croizet, J. C., \& Claire, T. (1998). Extending the concept of stereotype threat to social class: The intellectual underperformance of students from low socioeconomic backgrounds. Personality and Social Psychology Bulletin, 24(6), 588-594. doi: 10.1177/0146167298246003

Darnon, B., \& Butera, F. (2005). Buts d'accomplissement, stratégies d'étude, et motivation intrinsèque: présentation d'un domaine de recherche et validation française de l'échelle d'Elliot et McGregor (2001) [Achievement goals, study strategies, and intrinsic motivation: Presenting a domain of research and the French validation of Elliot and McGregor's (2001) scale]. L'Année Psychologique, 105, 105-131. doi: 10.3406/psy.2005.3821

Darnon, C., Butera, F., Mugny, G., Quiamzade, A., \& Hulleman, C. S. (2009). "Too complex for me!" Why do performance-approach and performanceavoidance goals predict exam performance?
European Journal of Psychology of Education, 24(4), 423. doi: 10.1007/BF03178759

Darnon, C., Jury, M., \& Aelenei, C. (2018). Who benefits from mastery-approach and performanceapproach goals in college? Students' social class as a moderator of the link between goals and grade. European Journal of Psychology of Education, 33(4), 713-726. doi: 10.1007/s10212017-0351-z

Deemer, E. D., Smith, J. L., Carroll, A. N., \& Carpenter, J. P. (2014). Academic procrastination in STEM: Interactive effects of stereotype threat and achievement goals. The Career Development Quarterly, 62(2), 143-155. doi: 10.1002/j.21610045.2014.00076.x

DeRosa, E., \& Dolby, N. (2014). "I don't think the university knows me.": Institutional culture and lower-income, first-generation college students. InterActions: UCLA Journal of Education and Information Studies, 10(2).

Destin, M., \& Debrosse, R. (2017). Upward social mobility and identity. Current Opinion in Psychology, 18, 99-104. doi: 10.1016/j.copsyc.2017.08.006.

Dickhäuser, C., Buch, S. R., \& Dickhäuser, O. (2011). Achievement after failure: The role of achievement goals and negative self-related thoughts. Learning and Instruction, 21(1), 152162. doi: 10.1016/j.learninstruc.2010.01.002

Dompnier, B., Darnon, C., \& Butera, F. (2013). When performance-approach goals predict academic achievement and when they do not: A social value approach. British Journal of Social Psychology, 52(3), 587-596. doi: $10.1111 /$ bjso. 12025

Durante, F., Tablante, C. B., \& Fiske, S. T. (2017). Poor but warm, rich but cold (and competent): Social classes in the stereotype content model. Journal of Social Issues, 73(1), 138-157. doi: 10.1111/josi.12208

Durik, A. M., Lovejoy, C. M., \& Johnson, S. J. (2009). A longitudinal study of achievement goals for college in general: Predicting cumulative GPA and diversity in course selection. Contemporary Educational Psychology, 34(2), 113-119. doi: 10.1016/j.cedpsych.2008.11.002

Dweck, C. S. (1986). Motivational processes affecting learning. American Psychologist, 41(10), 10401048. doi: 10.1037/0003-066X.41.10.1040

Elliot, A. J. (1999). Approach and avoidance motivation and achievement goals. Educational Psychologist, 34(3), 169-189. doi: $10.1207 / \mathrm{s} 15326985 \mathrm{ep} 3403$ _3

Elliot, A. J., \& Church, M. A. (1997). A hierarchical model of approach and avoidance achievement motivation. Journal of Personality and Social Psychology, 72(1), 218-232. doi: 10.1037/00223514.72.1.218

Elliot, A. J., \& Harackiewicz, J. M. (1996). Approach and avoidance achievement goals and intrinsic motivation: A mediational analysis. Journal of Personality and Social Psychology, 70(3), 461475. doi: 10.1037/0022-3514.70.3.461 
Elliot, A. J., \& McGregor, H. A. (2001). A $2 \times 2$ achievement goal framework. Journal of Personality and Social Psychology, 80(3), 501. doi: 10.1037/0022-3514.80.3.501

Elliot, A. J., \& Murayama, K. (2008). On the measurement of achievement goals: Critique, illustration, and application. Journal of Educational Psychology, 100(3), 613-628. doi: 10.1037/0022-0663.100.3.613

Elliot, A. J., Murayama, K., \& Pekrun, R. (2011). A $3 \times 2$ achievement goal model. Journal of Educational Psychology, 103(3), 632-648. doi: 10.1037/a0023952

Elliott, E. S., \& Dweck, C. S. (1988). Goals: An approach to motivation and achievement. Journal of Personality and Social Psychology, 54(1), 5-12. doi: 10.1037/0022-3514.54.1.5

Fiske, S. T., Cuddy, A. J., Glick, P., \& Xu, J. (2002). A model of (often mixed) stereotype content: competence and warmth respectively follow from perceived status and competition. Journal of Personality and Social Psychology, 82(6), 878902. doi: 10.1037//0022-3514.82.6.878

Goudeau, S., \& Croizet, J. C. (2017). Hidden advantages and disadvantages of social class: How classroom settings reproduce social inequality by staging unfair comparison. Psychological Science, 28(2), 162-170. doi: $10.1177 / 0956797616676600$

Grant, H., \& Dweck, C. S. (2003). Clarifying achievement goals and their impact. Journal of Personality and Social Psychology, 85(3), 541553. doi: 10.1037/0022-3514.85.3.541

Halabi, S., Dovidio, J. F., \& Nadler, A. (2008). When and how do high status group members offer help: Effects of social dominance orientation and status threat. Political Psychology, 29(6), 841-858. doi: 10.1111/j.1467-9221.2008.00669.x

Harackiewicz, J. M., Barron, K. E., Pintrich, P. R., Elliot, A. J., \& Thrash, T. M. (2002). Revision of achievement goal theory: Necessary and illuminating. Journal of Educational Psychology, 94(3), 638-645. doi: 10.1037/0022-0663.94.3.638

Harackiewicz, J. M., Barron, K. E., Tauer, J. M., \& Elliot, A. J. (2002). Predicting success in college: A longitudinal study of achievement goals and ability measures as predictors of interest and performance from freshman year through graduation. Journal of Educational Psychology, 94(3), 562-575. doi: 10.1037/00220663.94.3.562

Harackiewicz, J. M., Barron, K. E., Tauer, J. M., Carter, S. M., \& Elliot, A. J. (2000). Short-term and long-term consequences of achievement goals: Predicting interest and performance over time. Journal of Educational Psychology, 92(2), 316-330. doi: 10.1037/0022-0663.92.2.316

Howell, A. J., \& Watson, D. C. (2007). Procrastination: Associations with achievement goal orientation and learning strategies. Personality and Individual Differences, 43(1), 167-178. doi: 10.1016/j.paid.2006.11.017
Huang, C. (2012). Discriminant and criterion-related validity of achievement goals in predicting academic achievement: A meta-analysis. Journal of Educational Psychology, 104(1), 48-73. doi: 10.1037/a0026223

Hulleman, C. S., Schrager, S. M., Bodmann, S. M., \& Harackiewicz, J. M. (2010). A meta-analytic review of achievement goal measures: Different labels for the same constructs or different constructs with similar labels?. Psychological Bulletin, 136(3), 422-449. doi: 10.1037/a0018947

Ivcevic, Z., \& Kaufman, J. C. (2013). The can and cannot do attitude: How self-estimates of ability vary across ethnic and socioeconomic groups. Learning and Individual Differences, 27, 144-148. doi: 10.1016/j.lindif.2013.07.011

Jetten, J., Iyer, A., Tsivrikos, D., \& Young, B. M. (2008). When is individual mobility costly? The role of economic and social identity factors. European Journal of Social Psychology, 38(5), 866-879. doi: 10.1002/ejsp.471

Jost, J. T., Gaucher, D., \& Stern, C. (2015). The world isn't fair": A system justification perspective on social stratification and inequality. APA handbook of personality and social psychology, 2, 317-340. doi: 10.1037/14342-012

Jury, M., Bruno, A., \& Darnon, C. (2018). Doing better (or worse) than one's parents: Social status, mobility, and performance-avoidance goals. British Journal of Educational Psychology,88(4), 659-674. doi: 10.1111/bjep. 12210

Jury, M., Smeding, A., Court, M., \& Darnon, C. (2015). When first-generation students succeed at university: On the link between social class, academic performance, and performanceavoidance goals. Contemporary Educational Psychology, 41, 25-36. doi: 10.1016/j.cedpsych.2014.11.001

Jury, M., Smeding, A., Stephens, N. M., Nelson, J. E., Aelenei, C., \& Darnon, C. (2017). The Experience of low SES students in Higher Education: Psychological barriers to success and interventions to reduce social-class inequality. Journal of Social Issues, 73(1), 23-41. doi: 10.1111/josi.12202

Kaplan, A., \& Middleton, M. J. (2002). Should childhood be a journey of a race? Response to Harackiewicz et al.(2002). Journal of Educational Psychology, 94, 646-48. doi: 10.1037/00220663.94.3.646

Karabenick, S. A. (2003). Seeking help in large college classes: A person-centered approach. Contemporary Educational Psychology, 28(1), 37-58. doi: 10.1016/S0361476X(02)00012-7

Karabenick, S. A. (2004). Perceived achievement goal structure and college student help seeking. Journal of Educational Psychology, 96(3), 569-581. doi: 10.1037/0022-0663.96.3.569

Keys, T. D., Conley, A. M., Duncan, G. J., \& Domina, T. (2012). The role of goal orientations for adolescent mathematics 
achievement. Contemporary

47-54. doi:

10.1016/j.cedpsych.2011.09.002

King, R. B. (2016). Is a performance-avoidance achievement goal always maladaptive? Not necessarily for collectivists. Personality and Individual Differences, 99, 190-195. doi: 10.1016/j.paid.2016.04.093

Kraus, M. W., Horberg, E. J., Goetz, J. L., \& Keltner, D. (2011). Social class rank, threat vigilance, and hostile reactivity. Personality and Social Psychology Bulletin, 37(10), 1376-1388. doi: 10.1016/j.paid.2016.04.093

Kraus, M. W., Piff, P. K., Mendoza-Denton, R., Rheinschmidt, M. L., \& Keltner, D. (2012). Social class, solipsism, and contextualism: How the rich are different from the poor. Psychological Review, 119(3), 546-572. doi: 10.1037/a0028756

Kraus, M. W., \& Stephens, N. M. (2012). A road map for an emerging psychology of social class. Social and Personality Psychology Compass, 6(9), 642656. doi: 10.1111/j.1751-9004.2012.00453.x

Kudrna, L., Furnham, A., \& Swami, V. (2010). The influence of social class salience on self-assessed intelligence. Social Behavior and Personality: An International Journal,38(6), 859-864. doi: 10.2224/sbp.2010.38.6.859

Levin, S., Federico, C. M., Sidanius, J., \& Rabinowitz, J. L. (2002). Social dominance orientation and intergroup bias: The legitimation of favoritism for high-status groups. Personality and Social Psychology Bulletin, 28(2), 144-157. doi: 10.1177/0146167202282002

Linnenbrink-Garcia, L., Tyson, D. F., \& Patall, E. A. (2008). When are achievement goal orientations beneficial for academic achievement? A closer look at main effects and moderating factors. International Review of Social Psychology, 21(1), 19-70.

Lovejoy, C. M., \& Durik, A. M. (2010). Selfhandicapping: The interplay between self-set and assigned achievement goals. Motivation and Emotion, 34(3), 242-252. doi: 10.1007/s11031010-9179-4

Meece, J. L., Anderman, E. M., \& Anderman, L. H. (2006). Classroom goal structure, student motivation, and academic achievement. Annual Review of Psychology, 57, 487-503. doi: 10.1146/annurev.psych.56.091103.070258

Midgley, C., Kaplan, A., \& Middleton, M. (2001). Performance-approach goals: Good for what, for whom, under what circumstances, and at what cost?. Journal of Educational Psychology, 93(1), 77. doi: 10.1037/0022-0663.93.1.77

Moller, A. C., \& Elliot, A. J. (2006). The 2 x 2 achievement goal framework: An overview of

empirical research. In A. Mittel (Ed.), Focus on educational psychology (pp. 307-326).

NY: Nova Science Publishers, Inc.

Ostrove, J. M., \& Long, S. M. (2007). Social class and belonging: Implications for college adjustment. The Review of Higher
Education, 30(4),

363-389. doi: $10.1353 /$ rhe. 2007.0028

Poortvliet, P. M., \& Darnon, C. (2010). Toward a more social understanding of achievement goals: The interpersonal effects of mastery and performance goals. Current Directions in Psychological Science, 19(5), 324-328. doi: 10.1177/0963721410383246

Ramos-Sánchez, L., \& Nichols, L. (2007). Selfefficacy of first-generation and non-firstgeneration college students: The relationship with academic performance and college adjustment. Journal of College Counseling, 10(1), 6-18. doi: 10.1002/j.2161-1882.2007.tb00002.x

Roussel, P., Elliot, A. J., \& Feltman, R. (2011). The influence of achievement goals and social goals on help-seeking from peers in an academic context. Learning and Instruction, 21(3), 394-402. doi: 10.1016/j.learninstruc.2010.05.003

Rubin, M. (2012). Working-class students need more friends at university: A cautionary note for Australia's higher education equity initiative.Higher Education Research \& Development, 31(3), 431-433. doi: $10.1080 / 07294360.2012 .689246$

Senko, C., \& Harackiewicz, J. M. (2005). Regulation of achievement goals: The role of competence feedback. Journal of Educational Psychology, 97(3), 320-336. doi: 10.1037/00220663.97.3.320

Stephens, N. M., Fryberg, S. A., Markus, H. R., Johnson, C. S., \& Covarrubias, R. (2012). Unseen disadvantage: How American universities' focus on independence undermines the academic performance of first-generation college students. Journal of Personality and Social Psychology, 102(6), 1178-1197. doi: 10.1037/a0027143

Stephens, N. M., Brannon, T. N., Markus, H. R., \& Nelson, J. E. (2015). Feeling at home in college: Fortifying school-relevant selves to reduce social class disparities in higher education. Social Issues and Policy Review, 9(1), 1-24. doi: 10.1111/sipr.12008

Urdan, T. (2004). Predictors of academic selfhandicapping and achievement: Examining achievement goals, classroom goal structures, and culture. Journal of Educational Psychology, 96(2), 251-264. doi: 10.1037/00220663.96.2.251

Van Yperen, N. W., Blaga, M., \& Postmes, T. (2014). A meta-analysis of self-reported achievement goals and nonself-report performance across three achievement domains (work, sports, and education). PloS one, 9(4), e93594. doi: 10.1371/journal.pone.0093594

Van Yperen, N. W., Blaga, M., \& Postmes, T. (2015). A meta-analysis of the impact of situationally induced achievement goals on task performance. Human Performance, 28(2), 165182. doi: 10.1080/08959285.2015.1006772 